\title{
IAMJ
}

INTERNATIONAL

AYURVEDIC

MEDICAL JOURNAL

Case Report

ISSN: 2320-5091

Impact Factor: 6.719

\section{ROLE OF AYURVEDA DRUGS IN TREATMENT OF SHVITRA: A CASE STUDY}

\author{
$\underline{\text { Sangeeta Saini }}^{1}, \underline{\text { Sonam Sain }}^{2}, \underline{\text { Mahendra Prasad }}^{3}, \underline{\text { Sarika Yadav }}^{4}$ \\ ${ }^{1} \mathrm{PG}$ Scholar, ${ }^{2} \mathrm{PG}$ Scholar, ${ }^{3}$ Associate Professor, ${ }^{4}$ Assistant Professor, \\ PG Department of Kriya Sharir, National Institute of Ayurveda, Jaipur, Rajasthan-302002, India
}

Corresponding Author: sangeetasaine26@gmail.com

https://doi.org/10.46607/iamj17p5062021

(Published online: September 2021)

Open Access

(C) International Ayurvedic Medical Journal, India 2021

Article Received: 01/09/2021 - Peer Reviewed: 11/09/2021 - Accepted for Publication: 12/09/2021

Check for updates

\section{ABSTRACT}

The term Kushtha is used in Ayurveda to describe the majority of skin diseases. In the Ayurvedic Samhita, Shvitra is one of the kinds of Kushtha that occurs due to vitiation of Tridoshas and Dushya such as Rakta, Mamsa, and Meda. ${ }^{l}$ Shvitra is mentioned in every classic, including the Bruhatrayees and Laghutrayees. Vitiligo, an acquired pigmentary illness of unknown aetiology, is the most common cause of depigmentation in the globe, with a prevalence of $1 \%^{2}$. Vitiligo is characterized by the appearance of white patches in the skin or hair as a result of the loss of functional melanocytes in the skin or hair, or both known as Shvitra in Ayurveda. A female patient, aged 19, who had been suffering from white spots on her face for 11 years was treated with Shaman Chikitsa over a period of 24 months, with follow-up every 30 days in between. Relief from the complaints was measured by changes in patch size gradually. The patch's size was almost cured after 24 months of treatment. The results of this case study showed that Ayurveda therapy, both internal and external, was effective in the treatment of Shvitra over a period of 24 months. The efficacy of Ayurvedic therapy was demonstrated in this case study.

Keyword: Shvitra, Leukoderma, Bakuchi, Trivang Bhasm

\section{INTRODUCTION}

Shvitra is a sickness that is mentioned in almost all Ayurvedic scriptures. Daruna, Aruna, and Kilasa ${ }^{3}$ are the names given to it. Shvitra is caused by the vitia- tion of the Vata, Pitta, and Kapha Doshas, according to Ashtanga Samgraha. Shvitra is produced when vitiated Tridosha invades the Rasa, Rakta, and 
Mamsa Dhatus. This disease causes white spots or discolouration on the skin, hence the name Shvitra. As a result, it is a depigmentation illness

The largest organ in the human body is the skin which covers and protects the body from physical, chemical, and mechanical harm. It also serves as a mirror for our bodies. Any disruption in skin texture leads to physical as well as mental sickness to the human body. It is a social issue that affects people all across the world, not just in India. It has been noticed since the beginning of time. Bhrajaka Pitta is involved in this condition. It's a skin condition caused by a lack of melanin pigment. We discovered a description of Shvitra from the Vedic period. We found detailed descriptions of Shvitra as synonyms, aetiology, kinds, SadhyaAsadhyatva, and Chikitsayojana in Charaka Samhita, Susruta Samhita, Ashtanga Sangraha, Ashtanga Hridaya, and other classical books. The clinical condition of the disease vitiligo can be compared to disease Shvitra in terms of symptomatology (white colour patch). Shvitra is described in Ayurveda as Khshudrkushta. While explaining the Nidan of Shvitra in the Charak Samhita, the main causes of Shvitra, according to Acharya Charak, are Virudhaaharvihar (unhealthy meals) and Paap karmas (bad deeds) ${ }^{4}$.

\section{MATERIAL AND METHODS AIM AND OBJECTIVE}

To investigate the case of Shvitra using Ayurveda.

To investigate the role of Ayurvedic medicine in the treatment of Shvitra.

\section{CASE REPORT}

19 years old unmarried female was presented with a history of Shvitra. The disease was in the active stage and new spots were increasing gradually. The patient visited in the OPD of Skin Care Unit, Sharir Kriya department, NIA Jaipur.

\section{CHIEF COMPLAINTS}

- White patch on right side of the face (sweta varnta)

- No itching

- No pain

\section{History of Present Illness}

The patient had white patches on the right side of the face in scattered form for 10 years and gradual increment in the last few months. She took Ayurvedic medication from Avadhuta Bhagwan Ram kushtha Seva ashrama, Padav Varanasi in 2018 and after that had Allopathic medication history including corticosteroid, and multivitamins internal and PUVA and external applications. She had found some improvement in starting phase of the treatment, but then there was no progress in that condition for the last 4 years. So, she came to NIA OPD in August 2019 for Ayurvedic medication.

\section{History}

Family history in the first-degree relation was negative. There was no personal history of autoimmune disorders (like Atopic dermatitis, psoriasis, Asthma, etc). There was no personal history of trauma or surgery, any major psychological disorder, endocrinal disorder (Diabetes).

\section{Personal History}
Age - 19
Appetite - normal
Sex - female
Sleep - adequate
Occupation - student
Bowel - clear
B.P $-110 / 70 \mathrm{~mm} / \mathrm{Hg}$

\section{TREATMENT SCHEDULE}

\begin{tabular}{|c|c|c|c|}
\hline Date & Drug & Dose & Duration \\
\hline \multirow[t]{4}{*}{$29 / 6 / 2019$} & $\begin{array}{l}\text { Shuddha Gairik - } 250 \mathrm{mg} \\
\text { Godanti- } 250 \mathrm{mg} \\
\text { Rasmanikya- } 125 \mathrm{mg} \\
\text { Bakuchi-4 gram } \\
\text { Manjishtha -2 gram }\end{array}$ & After mixture all $3 \mathrm{gm} \mathrm{BD}$ & 24 months \\
\hline & Aarogyavardhini vati & 2 vati $B D$ & 24 months \\
\hline & Tab Pigmento & 2 Tab BD & 24 months \\
\hline & Syp. Leukoskin & $5 \mathrm{Ml} \mathrm{BD}$ & 24 months \\
\hline
\end{tabular}




\begin{tabular}{|l|l|l|l|}
\hline & Ointment Leukoskin & L/A & \\
\hline $16 / 10 / 2019$ & Complete same treatment & & \\
\hline $15 / 02 / 2020$ & $\begin{array}{l}\text { Complete same treatment } \\
\text { Complete same treatment + Trivang } \\
\text { Bhasm }\end{array}$ & & Continue yet \\
\hline $12 / 03 / 2020$ & Complete same treatment & & \\
\hline
\end{tabular}

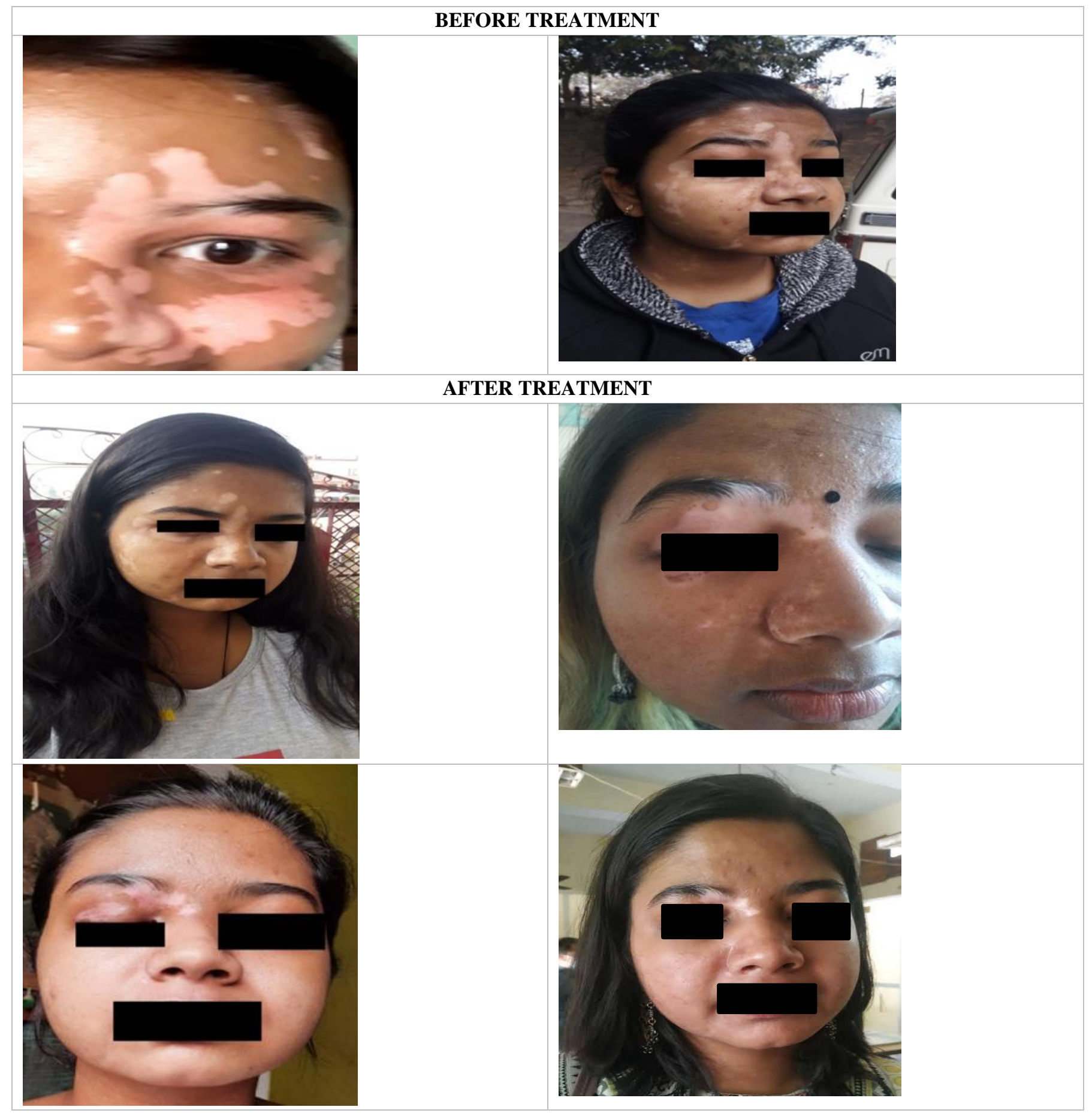




\section{DISCUSSION}

The Pitta (Bhrajaka Pitta) Pradhana Tridosha, which vitiates Tvaka (Rasa dhatu), Rakta, Mamsa, and Lasika (lymph), i.e., Kustha dravya sangraha ${ }^{5}$ is the key causative component in the manifestation of Shvitra Kustha (the sevenfold pathogenic substance of Kustha). Consumption of causative factors of Shvitra, causes Dosha vitiation and Shaithilyata (looseness) in the Dhatus (Tvaka, Rakta, Mamsa, Lasika) simultaneously.

Suddha Gairik has Madhur Rasa and Sheet Veerya ${ }^{6}$ which balances increased Rakta and Pitta in the body.

Rasmanikya has Kushthgan properties. The major ingredients of Rasmanikya are Tamara Bhasma, Hartala and Abhrak Bhasma. Tamara Bhasma helps in red blood cells formation thus restore the complexion and colour of skin. The presence of Tamara Bhasma reduces the chances of disease which can arise due to the vitiation of blood. Hartala offers beneficial effects in skin diseases like, itching, eczema etc. $A b$ hrak Bhasma another component of Rasmanikya boosts immunity thus prevent skin infection ${ }^{7}$, it also imparts strength thus maintain physical compatibility and skin integrity. Godanti has Sheet Guna and also Pittashamak effect on vitiated Pitta. Hence is useful in Shvitra.

Aarogya signifies 'good health' whereas Vardhini stands for improver, i.e., a formulation that completely eradicates diseases and improve or promote good health. Aarogyavardhini Vati is widely mentioned in the ancient texts of Ras Ratna Samucchya for the treatment of Kushtha. Its major component is Kutaki which is highly effective in normalising the Tridosha and has Tikta Rasa. All these properties are good for treating skin diseases and detoxify the body.

Arogyavardhini Vati does the Shoshan ( assimilation) of different excess Snigdhadravyas ( unctuous substances) present in the body. It also does the Pachan ( digestion) of Drava ( liquid) and Kleda ( clammy) and does the Raktasodhan ( purifies blood). It reduces Dravatva, Snigdhatva in Meda dhatu. . Guduchi and Amalaki are Rasayana drugs that help in the rejuvenation process.
In Trivang Bhasm, Vang has Deepan, Varnya, Kaphaghn, Krmighn, Vrnaropan, Srotosodhak ${ }^{9}$ properties and is very useful in chronic skin diseases. Yashad Bhasm has more Sheet Guna and Kashaya Rasa and is effective in treating Rakta and Pitta Vikar.

Tablet Pigmento, Leukoskin syrup and ointment Leukoskin are herbal formulation, and their main ingredient is Bakuchi. Bakuchi (Psoralea corylifolia Linn.) is a renowned herb with many therapeutic properties. It contains psoralens which cause erythematic and residual pigmentation over hypopigmented skin. In Leucoderma melanoblastic cells are not functioning properly and their stimulation by oil leads to form an exude pigment which gradually diffuses into the decolourized areas ${ }^{10}$. Manjishtha is mainly a blood purifier. It detoxifies blood and aids to eliminate toxins accumulated in the body. It increases skin glow by purifying blood.

\section{CONCLUSION}

The patient suffering from chronic Vitiligo was treated with Ayurvedic management along with Diet restriction. From the above discussion, it is concluded that the Ayurvedic line of management i.e., Shaman Chikitsa and the local application of Leukoskin are successful in the management of Shvitra. As far As the disease chronicity is concerned, for more effective results, the treatment duration should be increased.

\section{REFERENCES}

1. Agnivesh Charak Samhita Vidyotini Hindi Commentary by Pt. Kashinath Sastri, caukhamba Bharati Academy, Varanasi, Reprint 2002; Chikitsa sthana 7/173-174-page no. 224.

2. John A. Hunter ed, Davidson,s principle and practise of medicine, edition- 19, 2002, chapter -21 Churvhill Livingstone. Page no. 1086-1087

3. Agnivesh Charak Samhita Vidyotini Hindi Commentary by Pt. Kashinath Sastri, caukhamba Bharati Academy, Varanasi, Reprint 2002; Chikitsa sthana 7/173.

4. Agnivesh Charak Samhita Vidyotini Hindi Commentary by Pt. Kashinath sastri, caukhamba Bharati Academy, Varanasi, Reprint 2002; Chikitsa sthana 7/177. 
5. Agnivesh Charak Samhita Vidyotini Hindi Commentary by Pt. Kashinath sastri, caukhamba Bharati Academy, Varanasi, Reprint 2002; Nidan sthana 5/3.

6. Ayurvediya rasshastra by Dr Chandrabhushan Jha Reprint 2021; chapter 6-page no. 248.

7. Dr Vishal Shivhare1*, Dr Nitin Tiwari Shivhare V, Tiwari N, Ayurveda Perspective of Rasamanikyaand its Role in Skin Disorders: A Review, Journal of Drug Delivery and Therapeutics. 2019; 9(6-s):267-269

8. Santosh Pal, A Ramamurthy, Bidhan Mahajon Arogyavardhini Vati: A theoretical analysis http://www.jsirjournal.com/Vol5_Issue6_05.pdf

9. Shivhare V, Tiwari N, Ayurveda Perspective of Rasamanikyaand its Role in Skin Disorders: A Review, Journal of Drug Delivery and Therapeutics. 2019; 9(6-s):267-269

10. Dr.Mrs .Vedashri A.Kalavade,Dr.Satish S.Chapadgaonkar a review of the effect of bakuchi on shwitra kushta http://www.ijsdr.org/papers/IJSDR1907051.pdf

\section{Source of Support: Nil Conflict of Interest: None Declared}

How to cite this URL: Sangeeta Saini et al: Role Of Ayurveda Drugs In Treatment Of Shvitra: A Case Study. International Ayurvedic Medical Journal \{online\} 2021 \{cited September 2021\} Available from: http://www.iamj.in/posts/images/upload/3152_3156.pdf 